\title{
The Implementation of the Authentic Assessment in EFL Classes in Erbil
}

\author{
Venera Ulker ${ }^{1} \&$ Yunus Yildiz ${ }^{2} \&$ Tina Firyad Barzani ${ }^{3}$ \\ 1,2English Language Teaching Department, Faculty of Education, Tishk International University, Erbil, \\ Iraq \\ ${ }^{3}$ Independent Researcher, Erbil, Iraq \\ Correspondence: Venera Ulker, Tishk International University, Erbil, Iraq \\ Email: venera.ulker@tiu.edu.iq
}

Doi: 10.23918/ijsses.v8i2p206

\begin{abstract}
To prepare students for their professional life through appropriate instruction and context, the most effective assessment types should be chosen to assess them. So, this study's aim is to find out how frequently authentic assessment is applied in English foreign language classes in Erbil, Iraq. The major problem is that many teachers and educators complain that the results of examinations and tests are not satisfactory and do not represent the actual level of student's language proficiency and this is due to inappropriate testing, the lack of alignment between the content, methods of instruction, lack of appropriate equipment and inappropriate classroom environment. This is why it is essential to analyze the current situation - applied assessment practices and the attitude towards authentic assessment, and to develop suitable recommendations for English foreign language teachers and educators. This study used quantitative approach to solve the problem and 95 teachers participated in the survey. The results of the questionnaire show that the significance of authentic assessment is well recognized by the teacher participants, and they try using it like making informal observations in the classroom. But when it comes to applying the formal types of assessment most of the respondents are still using the traditional types of assessment more often. Moreover, results of this research will be significant to helping teachers with implementing authentic assessment more by providing them with appropriate equipment, knowledge, and instructions.
\end{abstract}

Keywords: Authentic Assessment, Traditional Assessment, Assessment in Erbil, Assessment

\section{Introduction}

\subsection{Background Information}

How can a teacher effectively assess his/her students' learning progress? What are the most appropriate assessment tools? Teachers may have different answers to these questions. It is necessary to find ways for increasing the teachers' awareness of the existing assessment practices, and to train them in choosing the most appropriate ways of assessment of the attainment of their students' learning objectives. The studies in the field of language assessment show that one of the most recommended type of assessment is authentic assessment (Archbald \& Newman, 1988; Ferguson, 2018; Capperucci, 2019; Butler, 2020).

Received: March 12, 2021

Accepted: June 20, 2021

Ulker, V., Yildiz, Y., \& Barzani, T.F. (2021). The Implementation of the Authentic Assessment in EFL Classes in Erbil. International Journal of Social Sciences \& Educational Studies, 8(2), 206-221. 
Authentic assessment is believed to be realistic because it requires students to demonstrate the knowledge and skills, they have obtained through application then to the new situations and/or to complete real-life tasks. The authentic assessment and its principles must be scrupulously studied before application in order to form its structure aligned with the nature of the course/subject being assessed. So, philosophy, psychology, linguistic perspective, theories, principles, available documents, etc. are needed to be considered. Thus, depending on these elements, the development and implementation of the authentic assessment must be carefully planned in teaching and learning.

This study deals with perception and implementation of the authentic assessment by English language teachers in Erbil educational institutions. It focuses on the teachers believes about the authentic assessment and the types of assessment that teacher use to encourage their students to learn English language in Kurdistan region especially in Erbil, as well as the obstacles that prevent educators from application of the authentic assessment.

\subsection{Problem Statement}

English foreign language teachers are faced with problems in assessing their students' learning process that need urgent solutions. The major problem is that many teachers and educators complain that the results of examinations and tests are not satisfactory and do not represent the actual level of student's language proficiency. This means that students' performance has been expected to be better than the results that have been achieved from the tests, or vice versa, and this is due to frustrations they faced during their studying and learning period: inappropriate testing, the lack of alignment in content, methods of instruction, assessment, and the desired learning outcomes, etc. This is why it is essential to analyze the current situation - applied assessment practices and the attitudes towards authentic assessment to develop suitable menu-recommendations for EFL teachers and educators.

\subsection{Research Questions}

This research paper attempts to answer the following questions:

1. What type/s of assessment do EFL teachers prefer?

2. What are the beliefs of the EFL teachers about authentic assessment?

3. What type of assessment do EFL teachers use in Erbil, Iraq?

4. What practical recommendations can be given to Kurdistan EFL teachers to improve assessment procedures and education in general?

\subsection{Aim of the Research}

The aims of the study include:

1. Investigating the types of the assessment used by EFL teachers.

2. Finding out the types of assessment EFL teachers prefer.

3. Finding out EFL teachers think about authentic assessment.

4. Finding the best ways for assessing students' abilities and their proficiency in learning English at different levels. 


\subsection{Methods of the Research}

Quantitative approach with the element of qualitative research has been adopted for achieving the objectives of this study. A questionnaire was designed on Google Form and the link was sent to the EFL teachers in the region to collect the data.

\subsection{Scope of the Study}

The study is limited to the authentic assessment implementation in English as a foreign language classes in schools and universities in Erbil, Kurdistan. 95 randomly chosen teachers from different schools and universities responded to the survey.

\subsection{Significance of the Study}

The focus of this study is to determine whether EFL teachers implement authentic assessment or not. The findings seek to increase the awareness of the authentic type of assessment to assess their students effectively. It is important for students to be assessed by the most effective and reliable type of assessment that will help them to improve themselves through it. This study is believed to be beneficial for EFL teachers, as well as educators, policymakers, and administrators in the Ministry of Education and Ministry of Higher Education.

\section{Literature Review}

\subsection{Authentic Assessment}

Authentic assessment as a way of measuring students' knowledge and skills is not new in professional training programs such as health care education, applied science, engineering, etc. However, in the programs where pen-and-paper exams are the most frequent if not the only way of assessment, authentic assessment has become an alternative way of assessment that rapidly gains its popularity. Every discipline has its own specific unique peculiarities, documents, demands, procedures that identify what is authentic and what is not. This is why the definition of the term authentic assessment can vary.

Authenticity was defined by Bachman and Palmer (1995) as "the degree of correspondence of the characteristics of a given language test tasks to the features of a target language tasks" (p. 23). While Bagnato (2007) defines it as "a kind of assessment that directly measures student's' performance through real life tasks or product such as creating an original piece of artwork, writing a paper delivering speech and so on" (p. 27-28).

In contrast, Wiggins (1989) states that "the authentic tests are contextualized, complex, intellectual challenges do not fragment, and static bits or tasks" (p. 711). Moreover, authentic tasks aim to assess repertories and behaviors of the students; they do not have to memorize and guessed one shot responses are not reflected. Also, Kerka (1995) states that "assessments are authentic when they have meaning in themselves, in the process of learning; they are measuring the value beyond the classroom and are meaningful to the learner" (p. 3). It means that students are given a chance to show their abilities in the real-life situations. 
Considering authentic assessment definitions and interpretations, in conclusion it can be said that this assessment type includes knowledge measurement, that is significant, meaningful, and a complete demonstrative/observable process that facilitates students' learning rather than something to be used just to assess the learning process. It was also found out that the major key of learning in authentic assessment is it focus on information processing. So, in a real sense, it is an evidenced way of learning to some appropriate standard. Despite of this, it should represent a performance that is meaningful and reflects real life tasks with different choices for the learning of students.

\subsection{Types of Authentic Assessment}

Among the wide variety of assessment tools and techniques an educator must choose the one/s that best align with the learning outcomes and demonstrates the theoretical and practical knowledge and skills gained by the target group of students. Having had made a decision in favor of authentic assessment it necessary to develop a menu of the types, forms, techniques and tools to help educators in assessment planning, development, and application.

Multiple authentic tools of assessment are used in education today including the following:

According to O'Malley \& Pierce (1996) there are eight types of authentic assessment (p. 11-14):

1. Oral interviews

For discovering students' comprehension over certain aspects of a language, the teachers may ask them to probe questions. Here students may orally respond to the questions. Student-student interviews can also be implemented, the teacher's role in the case is to observe and give constructive feedback.

2. Retelling

To determine reading strategies as well as comprehension and development of language, students produce oral reports or texts that are graded based on language competence or content as well as rubrics. Through reading or listening to the text students will retell its main ideas. Then probing questions can be asked by teachers and students about the text in order to explore their abilities and mastery over subject.

3. Writing sample

Students produce written documents, such as letters, essays, newspaper reports, or research papers. For example, it can be graded with rubrics or specific scales, which possess the guidelines of writing that can determine and examine the students' command over the assignment or work.

4. Exhibitions and projects

Projects are created by students working individually or in groups then presented in written and oral form. Students' presentations and /or written and oral reports are observed and graded with oriented scales and measurements as well as with rubrics.

5. Demonstrations and experiments

In language education students are required to follow some instructions/steps to apply theoretical or practical knowledge to the real-life situations and observe the results of this experiments to make conclusions and/or revisions, updates, word change, etc. to improve themselves. Demonstrations can be used to motivate students to share/exchange the information they have found on a given topic 
with the peers. By doing so, learners are exposed to the real-life situations and practice their oral and written skills.

6. Constructed response items

Students have to construct their responses either by evaluation of the situation/given information or giving explanations, examples, opinions, etc. The answers can be a short answer - one sentence, or a longer response: an essay or report, requiring students to provide more details.

7. Teacher observation

Teachers observe their students while they are working on the tasks, observe their daily interactions to ensure that the students are engaged in the tasks, and working productively. Recording observations with anecdotal notes or rating scales is highly recommended to enable teachers to provide feedback and track the learning process.

8. Portfolio

It is a purposeful collection of students' work or artifacts mastery or competence for some subjects, as well as the students' gradual own observations of his/her progress. It is an excellent way to demonstrate the students' gradual growth overtime.

In addition to the mentioned above types, Darling-Hammond, Falk, \& Ancess (2017) suggest using:

Self- and peer-evaluation using rubrics aiming to involve students into assessment process and focus on what was done well and what needs to be changed providing recommendations for improvement. This type of assessment allows learners to benefit from each other's' ideas as well as to improve their critical thinking and problem-solving skills. Another recommended tool is Performance tasks, which are usually indistinguishable in the instruction and enable teachers and students to learn what students have acquired and what further steps are needed to be taken.

Burke (2009) asserts journals and graphic organizers as separate types of authentic assessment aiming to focus on development of students' autonomy and self-directed learning. Burke (2009) also suggests using teacher prepared test on the condition of providing the questions and tasks to measure knowledge and skills in authentic context. 
Table 1: Examples of traditional and authentic assessment

\begin{tabular}{|l|l|}
\hline Traditional assessment task & Authentic assessment alternative \\
\hline $\begin{array}{l}\text { Match the words with their } \\
\text { definitions. }\end{array}$ & $\begin{array}{l}\text { Read the sentences and define the words in bold in } \\
\text { your own words }\end{array}$ \\
\hline $\begin{array}{l}\text { Write a paragraph about your last } \\
\text { holiday }\end{array}$ & $\begin{array}{l}\text { Write a post on your blog/Facebook/Instagram } \\
\text { about your last holiday. }\end{array}$ \\
\hline $\begin{array}{l}\text { Put the verbs in brackets in correct } \\
\text { form. }\end{array}$ & $\begin{array}{l}\text { Read the email (e.g., Grade Change Request, } \\
\text { Further Information Request, Informing the school } \\
\text { administration about the Corona virus } \\
\text { infection/testing positive, etc.) and review/make } \\
\text { necessary changes/edit it. Pay attention to the verb } \\
\text { forms. Then send it to the related person (teacher, } \\
\text { secretary, etc.) }\end{array}$ \\
\hline $\begin{array}{l}\text { Speaking exam: Students make } \\
\text { blind selection of the cards with } \\
\text { questions/topics then answer/speak. }\end{array}$ & $\begin{array}{l}\text { Students prepare oral presentations } \\
\text { Students record a video on a selected/given topic - } \\
\text { interview, how to tutorial, demonstration, etc. } \\
\text { Role-play } \\
\text { Drama }\end{array}$ \\
\hline $\begin{array}{l}\text { Multiple choice exam; True or } \\
\text { False tests. }\end{array}$ & $\begin{array}{l}\text { Demonstrations } \\
\text { Portfolios } \\
\text { Projects }\end{array}$ \\
\hline
\end{tabular}

\subsection{Authentic Assessment Principles}

It may not be possible to create a set of rules for designing and evaluating of the authentic assessment tasks since every case is unique and must be analyzed separately. However, there are some general principles that can serve as a guideline. Wiggins (1989), Winograd (1995), O'Malley \& Pierce, (1996) highlight the following characteristics of the authentic assessment:

- Authentic tasks are designed to be truly ready representatives of performance in the field; the problems of scoring, reliability, and logistics of testing should be considered.

- Authentic tasks give feedback to students, there must be a report or a descriptive rubric for students to refer to.

- Authentic tasks must provide the evidence of achieving the desired learning outcomes.

- In authentic tasks self-assessment plays a much greater role than conventional testing.

- The more realistic the tasks are, and the more authentic they are.

- Authentic tasks show a strong connection between the curriculum and the intended outcomes learning.

- The knowledge is based on the content and the future career.

- Authentic tasks do not disadvantage or advantage any student because are designed to be fair tasks.

- Authentic tasks keep students interested, they are designed to be motivational and fun. They are also challenging but they are possible to achieve.

- The focus of authentic tasks is meaningful goals. Authentic assessment identifies goals that can be placed on a continuum ranging from the very broad and general to the extremely specific and narrow. 
- The development of problem-solving as well as critical thinking is assured in authentic tasks.

The figure below proves the summary of the principals of the authentic assessment.

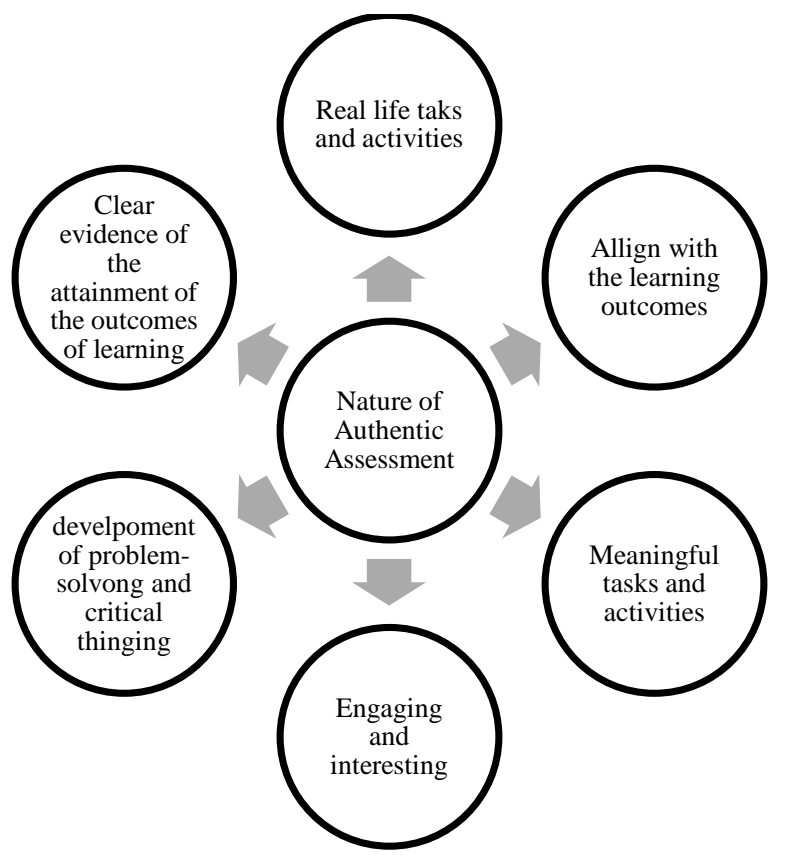

Figure 1: Nature of authentic assessment

\subsection{Pitfalls and Drawbacks of Authentic Assessment and Recommendations to Overcome Them}

Although the authentic assessment is a continuous process in schools, there are some hindering points on the application of the process. Table 2 is designed to demonstrate the obstacle educators can face during the application of the authentic assessment. 
Table 2: The obstacles and possible solutions of authentic assessment

\begin{tabular}{|c|c|}
\hline The Pitfalls and Drawbacks & Recommendations \\
\hline $\begin{array}{l}\text { Lack of support and learning } \\
\text { environment in the classroom which } \\
\text { makes students unwilling to carry } \\
\text { out the learning process properly. }\end{array}$ & $\begin{array}{l}\text { Providing a helpful and friendly learning environment } \\
\text { in the classroom. } \\
\text { State the purpose/learning objective of the task clearly } \\
\text { to make the assignment more meaningful. }\end{array}$ \\
\hline $\begin{array}{l}\text { Weak participation of students } \\
\text { because of feeling shy to express } \\
\text { their own points of view. }\end{array}$ & $\begin{array}{l}\text { Using brainstorming techniques to assess the student's } \\
\text { abilities and performance and encouraging them to } \\
\text { generate many new ideas to talk about during the } \\
\text { classroom period. }\end{array}$ \\
\hline $\begin{array}{l}\text { Lack of the information which affect } \\
\text { the teachers in progressing their } \\
\text { plans for assessing their students in } \\
\text { the classroom. }\end{array}$ & $\begin{array}{l}\text { Giving the students opportunities to voice their own } \\
\text { thoughts and actively communicate with one another } \\
\text { during daily activities in the classroom. } \\
\text { Involve students into needs analysis to reveal what } \\
\text { exactly students want and need to know and able to do. } \\
\text { Use check lists - for observations and students' self- } \\
\text { assessment. }\end{array}$ \\
\hline $\begin{array}{l}\text { Lack of friendly relationship which } \\
\text { discourages students to participate in } \\
\text { class activities. }\end{array}$ & $\begin{array}{l}\text { Asking students short questions that are related to the } \\
\text { subject before explaining the lesson in order to activate } \\
\text { background knowledge and attract their attention to the } \\
\text { subject. In other words, show students what they can } \\
\text { and know first (praising can be very motivating) then } \\
\text { drag the students' attention to what they need to } \\
\text { acquire to improve themselves. }\end{array}$ \\
\hline $\begin{array}{l}\text { Assessing large classes which } \\
\text { contain a large number of students is } \\
\text { a difficult process. }\end{array}$ & $\begin{array}{l}\text { Divide class into smaller groups giving each member } \\
\text { of a group a different role to contribute the group } \\
\text { project. } \\
\text { Use peer-checking asking students to evaluate each } \\
\text { other's projects according to a rubric and give } \\
\text { comments/recommendations. }\end{array}$ \\
\hline $\begin{array}{l}\text { Assessment procedure is not at an } \\
\text { appropriate level of challenges. }\end{array}$ & $\begin{array}{l}\text { Moving towards more authentic task and giving } \\
\text { students a clearer understanding of their } \\
\text { responsibilities. The difficulty of the tasks must be not } \\
\text { too easy nor too easy. Splitting the tasks into smaller } \\
\text { stages can also be a solution. }\end{array}$ \\
\hline
\end{tabular}

As any other assessment authentic assessment has its strength as well as limitations, however a careful planning and application enable teachers to avoid the pitfalls and assess students' attainment of the learning outcomes. Furthermore, the educators are strongly recommended to keep the records of what worked well and what needs improvement while using authentic assessment to make necessary changes and preparations to increase the effectiveness of the selected assessment task.

\subsection{Procedure of Authentic Assessment Implementation}

Implementation of authentic assessment in English language courses is not an easy task. The following actions and procedures can be recommended in order to increase the authenticity of the assessment: 
1. Building a team

An assessment team should be built and should include teachers, parents, and administrators, as well as students themselves, in order to discuss the authentic assessment program.

2. Identify the aim of authentic assessment

Having the clear understanding of the purpose of implementing the authentic assessment substantially help in choosing the material, design, and application procedures.

3. Specifying goals

Agreement should be made about the objectives of authentic assessment by the evaluation team. So, the focus is put on the aspects that really matter (primary goals) rather than the components that are less important.

4. Conducting training sessions on authentic assessment

Professional development can be maintained by planning information sharing sessions for teachers and other staff involved in the application of the assessment. Inviting the managers to care of these stuff development activities ensures that they are informed about the new types of assessment being used.

5. Collecting examples of authentic assessment

One of the best ways to begin the development and use of the authentic assessments is to look for examples of the assessment that suit the objectives and types of assessment that a teacher needs for his/her students. This will show the previous experience and give ideas for design and implementation.

6. Adapt existing or develop new ones.

The choice between the creating new assessment tasks or adapting the existing ones very much depends on the learning objectives and the security of the assessment (Ulker, 2017a). The new tasks may need piloting to prove its validity, while the existing tasks can be improved based on the feedback in form of written or oral reports. Furthermore, reusing the tasks may cause cheating and requires actions to be taken.

7. Piloting assessments

Even after very scrupulous planning, unanticipated weaknesses may be identified and require changes. Piloting aims to help educators to foreseen them before the actual application.

8. Review the assessment

The teacher should discuss the assessment with other members of the assessment team. Not only how well his/her students did, but also their perceptions of the assessments. Making changes in the assessments if students are unable to respond to certain items, lack of, for example, validity, reliability, practicality, etc.

Authentic assessment is cyclic process, so after completion of a task there should be an opportunity to improve/redo the tasks, as it very often possible in the real-live situations or navigating students in mastering their knowledge and skills.

Meaningful and significant measurement of knowledge is a postulate of authentic assessment (Ulker, 2017b). It is a complex process that facilitates students' learning rather than something done for only assessing processes. Moreover, the process of acquiring the information and mastering skills is what the authentic assessment stresses on and values as much as the final product. 
The process of learning and teaching together with the valid assessment is essential for training students to become independent life-long learners. Authentic assessment provides the teacher with feedback about students' progress, improves relationship between teachers as well as showing how appropriately the students have achieved the intended objectives and how effective the teaching has been in achieving its intended learning outcomes. Authentic assessment provides students with constructive feedback to enable the students to evaluate their performance against the standard expected, and consequently improve their work (Ulker, 2017c). Well-organized assessment motivates students to act and organize their work well and learn what is required. To sum up, authentic assessment is an evidenced way of learning to some appropriate standard, despite of this it should be close to the performance in real world contexts and should reflect and provide an opportunity to practice the real-life situations with multiple choices and solutions for student learning.

\section{Methodology}

\subsection{Setting and Respondents}

The present study was conducted during the spring term of the 2020-2021 academic year. English language teachers from different private and public educational institutions in Erbil city volunteered to complete an online google form survey. The total number of the responses received was exactly 95 responses. $47.9 \%$ of the responses were from university teachers, $48.9 \%$ of the responses were from schoolteachers and the others were from other educational institutions. The degree of respondents that completed the survey had varied from bachelor to $\mathrm{PhD}$ (BA-42.6\%, MA-34\%, $\mathrm{PhD} 22.3 \%$, higher national diploma-1.1\%). The years of teaching experience varied from 0 to more than 10 years: $22.3 \%$ of the respondents had $0-3$ years of teaching experience, $22.3 \%$ had 4-6 teaching experience, $21.3 \%$ had 7-10 teaching experience and 34\% had more than 10 years of experience. The wide variety of participants with different educational background and professional experience added dimensions to the research and allowed the researcher to receive more objective data and to make generalizations for wider populations.

\subsection{Survey Description}

To form and share this questionnaire with the participants' Google Form was used by the researcher. The questionnaire was composed of three sections: 1 demographic information (3 questions) and 2 parts of questions about authentic assessment perception and practices (section 2 - 10 questions and section 3 - 15 questions). The questions are in forms of checkboxes and Likert scales. Moreover, at the end of section 2 and section 3 an open-ended question was included to make the questionnaire more objective and receive more details about the respondents' experiences in using authentic assessment.

\section{Results and Discussion}

\subsection{Results}

The section 2 of the questionnaire contained the questions requiring the respondents to rate their answers from 1 - Never to 10 - Always. 
Table 3: Authentic assessment practices

\begin{tabular}{|c|c|c|c|c|c|c|c|c|c|c|}
\hline \multirow{2}{*}{ Statement } & \multicolumn{10}{|c|}{ Rating Scale } \\
\hline & 1 & 2 & 3 & 4 & 5 & 6 & 7 & 8 & 9 & 10 \\
\hline $\begin{array}{l}\text { I design my lessons } \\
\text { to help students to } \\
\text { translate issues and } \\
\text { situations (target } \\
\text { theoretical } \\
\text { knowledge) into } \\
\text { meaningful, } \\
\text { purposeful, and } \\
\text { clear tasks }\end{array}$ & $0 \%$ & $\begin{array}{l}1.1 \\
\%\end{array}$ & $\begin{array}{l}1.1 \\
\%\end{array}$ & $0 \%$ & $\begin{array}{l}5.3 \\
\%\end{array}$ & $9.5 \%$ & $8.4 \%$ & $24.2 \%$ & $\begin{array}{l}17.9 \\
\%\end{array}$ & $\begin{array}{l}32.6 \\
\%\end{array}$ \\
\hline $\begin{array}{l}\text { I engage students to } \\
\text { write/say sentences } \\
\text { expressing a } \\
\text { complete thought. }\end{array}$ & $0 \%$ & $\begin{array}{l}2.1 \\
\%\end{array}$ & $0 \%$ & $\begin{array}{l}2.1 \\
\%\end{array}$ & $\begin{array}{l}8.4 \\
\%\end{array}$ & $7.4 \%$ & $\begin{array}{l}11.6 \\
\%\end{array}$ & $18.9 \%$ & $\begin{array}{l}22.1 \\
\%\end{array}$ & $\begin{array}{l}27.4 \\
\%\end{array}$ \\
\hline $\begin{array}{l}\text { I assist students to } \\
\text { prepare criteria for } \\
\text { assessing their own } \\
\text { project. }\end{array}$ & $\begin{array}{l}1.1 \\
\%\end{array}$ & $\begin{array}{l}3.2 \\
\%\end{array}$ & $\begin{array}{l}3.2 \\
\%\end{array}$ & $\begin{array}{l}6.3 \\
\%\end{array}$ & $\begin{array}{l}5.3 \\
\%\end{array}$ & $\begin{array}{l}17.9 \\
\%\end{array}$ & $8.4 \%$ & $22.1 \%$ & $\begin{array}{l}12.6 \\
\%\end{array}$ & $\begin{array}{l}20 \\
\%\end{array}$ \\
\hline $\begin{array}{l}\text { I guide students to } \\
\text { apply their } \\
\text { knowledge to real } \\
\text { life problems. }\end{array}$ & $0 \%$ & $0 \%$ & $\begin{array}{l}1.1 \\
\%\end{array}$ & $\begin{array}{l}2.1 \\
\%\end{array}$ & $\begin{array}{l}4.2 \\
\%\end{array}$ & $7.4 \%$ & $\begin{array}{l}13.7 \\
\%\end{array}$ & $15.8 \%$ & $\begin{array}{l}30.5 \\
\%\end{array}$ & $\begin{array}{l}25.3 \\
\%\end{array}$ \\
\hline $\begin{array}{l}\text { I guide students to } \\
\text { use hand-on tasks to } \\
\text { conduct several } \\
\text { investigations. }\end{array}$ & $\begin{array}{l}2.1 \\
\%\end{array}$ & $\begin{array}{l}1.1 \\
\%\end{array}$ & $\begin{array}{l}1.1 \\
\%\end{array}$ & $\begin{array}{l}7.4 \\
\%\end{array}$ & $\begin{array}{l}7.4 \\
\%\end{array}$ & $\begin{array}{l}14.7 \\
\%\end{array}$ & $8.4 \%$ & $21.1 \%$ & $\begin{array}{l}18.9 \\
\%\end{array}$ & $\begin{array}{l}17.9 \\
5\end{array}$ \\
\hline $\begin{array}{l}\text { I ask students to } \\
\text { provide } \\
\text { explanations for } \\
\text { their responses. }\end{array}$ & $0 \%$ & $\begin{array}{l}1.1 \\
\%\end{array}$ & $\begin{array}{l}0.0 \\
\%\end{array}$ & $\begin{array}{l}1.1 \\
\%\end{array}$ & $\begin{array}{l}3.2 \\
\%\end{array}$ & $\begin{array}{l}10.5 \\
\%\end{array}$ & $9.5 \%$ & $17.9 \%$ & $\begin{array}{l}17.9 \\
\%\end{array}$ & $\begin{array}{l}38.9 \\
\%\end{array}$ \\
\hline $\begin{array}{l}\text { I assist students to } \\
\text { add supportive } \\
\text { details to } \\
\text { stories/presentations }\end{array}$ & $0 \%$ & $\begin{array}{l}1.1 \\
\%\end{array}$ & $0 \%$ & $\begin{array}{l}1.1 \\
\%\end{array}$ & $\begin{array}{l}4.2 \\
\%\end{array}$ & $\begin{array}{l}12.6 \\
\%\end{array}$ & $\begin{array}{l}14.7 \\
\%\end{array}$ & $24.2 \%$ & $\begin{array}{l}15.8 \\
\%\end{array}$ & $\begin{array}{l}26.3 \\
\%\end{array}$ \\
\hline $\begin{array}{l}\text { I ask students to co- } \\
\text { operate with peers } \\
\text { and school } \\
\text { personnel. }\end{array}$ & $0 \%$ & $\begin{array}{l}1.1 \\
\%\end{array}$ & $\begin{array}{l}2.1 \\
\%\end{array}$ & $\begin{array}{l}2.1 \\
\%\end{array}$ & $\begin{array}{l}3.2 \\
\%\end{array}$ & $\begin{array}{l}12.6 \\
\%\end{array}$ & $\begin{array}{l}11.6 \\
\%\end{array}$ & $17.9 \%$ & $\begin{array}{l}27.4 \\
\%\end{array}$ & $\begin{array}{l}22.1 \\
\%\end{array}$ \\
\hline $\begin{array}{l}\text { I make informal } \\
\text { observations about } \\
\text { how students are } \\
\text { responding to } \\
\text { instructions/reports. }\end{array}$ & $\begin{array}{l}1.1 \\
\%\end{array}$ & $\begin{array}{l}1.1 \\
\%\end{array}$ & $\begin{array}{l}2.1 \\
\%\end{array}$ & $\begin{array}{l}3.2 \\
\%\end{array}$ & $\begin{array}{l}4.2 \\
\%\end{array}$ & $8.4 \%$ & $\begin{array}{l}16.8 \\
\%\end{array}$ & $21.1 \%$ & $\begin{array}{l}23.2 \\
\%\end{array}$ & $\begin{array}{l}18.9 \\
\%\end{array}$ \\
\hline
\end{tabular}


The results of the second section of the survey show that almost all the participants (98\%) try to design their lessons implementing meaningful, purposeful and clear tasks. Nearly everyone (95\%) guides their students to apply the knowledge they receive during the lesson in solving real-life problems and use practical tasks to promote self-learning through investigations and discovery. In addition, most of the participants motivate their students to give full sentences to express their ideas and opinions providing an explanation for their responses as well as adding supportive details to their work. Furthermore, a great majority of the respondents (97\%) ask students to co-operate with their peers and school personnel.

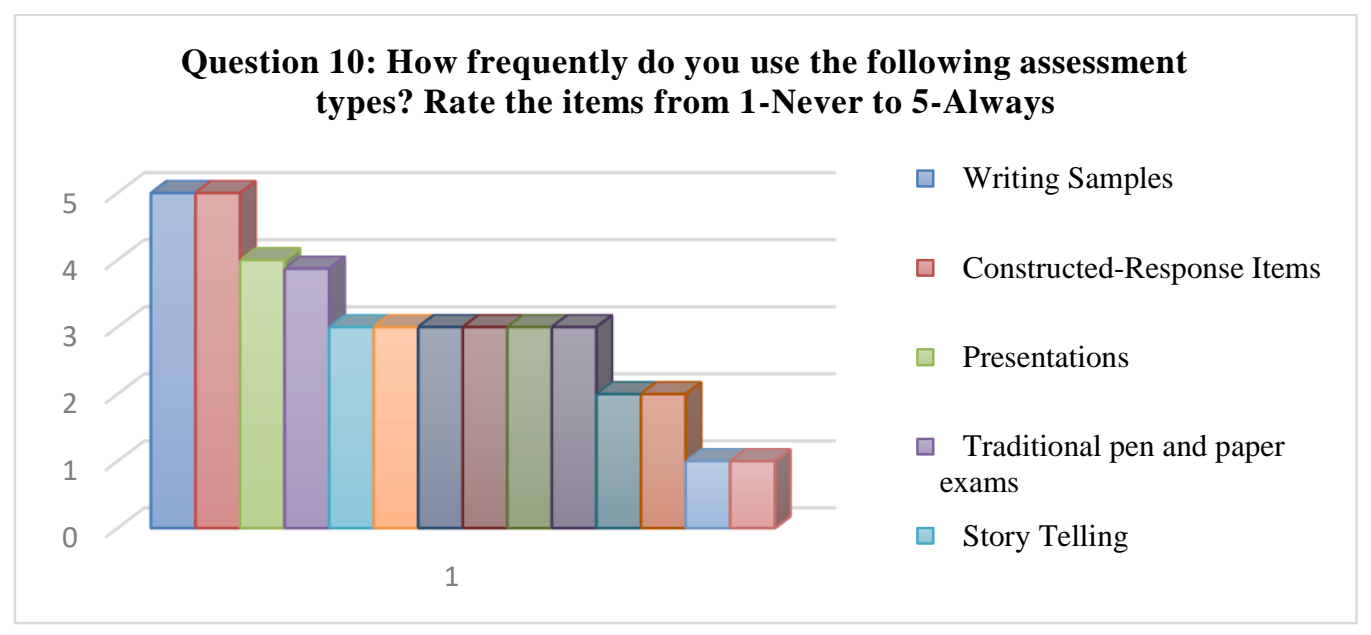

Figure 2: Use of different types of assessment

As it is shown in the figure above, writing samples and constructed-response items are the most frequently used types of assessment (Mean=5) and the traditional pen and paper exams are still among the most popular types of assessment (Mean=3.9). In most of the cases the reason is, as one of the respondents stated in the survey, the lack of time, resources, and facilities: "we are teaching in normal school. And in normal school we don't have time and good object and to prepare every sample and object to teach as professional school". However, teachers are also trying to implement authentic assessment by using presentations (Mean=4). The types of assessment such as storytelling, role-play, experiments, demonstrations, and exhibition have equal mean (Mean=3). Besides these types of assessment teachers also make informal observations to see how students work on projects and informally check comprehension by asking questions, as another respondent wrote in the survey "I usually ask them general questions at the end of each topic or session". $92.5 \%$ of the respondents involve students in preparing assessment criteria for their assignments so they become aware of what they do, what is important, and how it must be done.

The section 3 of the questionnaire contained questions that the respondent has to rate from 1 - totally disagree to 5 - totally agree. 
Table 4: Teachers' perception of authentic assessment

\begin{tabular}{|c|c|c|c|c|c|}
\hline \multirow{2}{*}{ Statement } & \multicolumn{5}{|c|}{ Rating Scale } \\
\hline & 1 & 2 & 3 & 4 & 5 \\
\hline $\begin{array}{l}\text { Authentic assessment requires students to } \\
\text { contrast and original response rather than } \\
\text { choose from a list of possibly correct answers. }\end{array}$ & $0 \%$ & $6.3 \%$ & $14.7 \%$ & $33.7 \%$ & $45.3 \%$ \\
\hline $\begin{array}{l}\text { Authentic assessment tasks foster higher order } \\
\text { thinking. }\end{array}$ & $0 \%$ & $3.2 \%$ & $20 \%$ & $28.4 \%$ & $48.4 \%$ \\
\hline $\begin{array}{l}\text { Authentic assessment assesses the process of } \\
\text { creating final product directly. }\end{array}$ & $2.1 \%$ & $4.2 \%$ & $20 \%$ & $50.5 \%$ & $23.2 \%$ \\
\hline $\begin{array}{l}\text { Authentic assessment requires a collaborative } \\
\text { effort to solve problems. }\end{array}$ & $1.1 \%$ & $0 \%$ & $17.9 \%$ & $46.3 \%$ & $34.7 \%$ \\
\hline Authentic assessment assesses projects. & $1.1 \%$ & $3.2 \%$ & $29.5 \%$ & $40 \%$ & $26.3 \%$ \\
\hline $\begin{array}{l}\text { Authentic assessment requires students to learn } \\
\text { to evaluate their own work using } \\
\text { predetermined criteria during authentic } \\
\text { assessment. }\end{array}$ & $1.1 \%$ & $3.2 \%$ & $21.1 \%$ & $31.6 \%$ & $43.2 \%$ \\
\hline $\begin{array}{l}\text { Authentic assessment uses students' work } \\
\text { which has been collected over time. }\end{array}$ & $1.1 \%$ & $1.1 \%$ & $16.8 \%$ & $40 \%$ & $41.1 \%$ \\
\hline $\begin{array}{l}\text { Authentic assessment is based on clear criteria } \\
\text { given to students. }\end{array}$ & $1.1 \%$ & $2.1 \%$ & $23.2 \%$ & $33.7 \%$ & $40 \%$ \\
\hline Authentic assessment lacks objectivity. & $14.7 \%$ & $15.8 \%$ & $36.8 \%$ & $24.2 \%$ & $8.4 \%$ \\
\hline $\begin{array}{l}\text { Authentic assessment allows for a particular } \\
\text { task to yield multiple scores in different } \\
\text { content domains. }\end{array}$ & $3.2 \%$ & $6.3 \%$ & $20 \%$ & $42.1 \%$ & $28.4 \%$ \\
\hline $\begin{array}{l}\text { Authentic assessment requires evaluation of } \\
\text { changes in performance over time. }\end{array}$ & $0 \%$ & $1.1 \%$ & $23.2 \%$ & $47.4 \%$ & $28.4 \%$ \\
\hline $\begin{array}{l}\text { Authentic assessment requires students to } \\
\text { incorporate information from many areas. }\end{array}$ & $2.1 \%$ & $5.3 \%$ & $24.2 \%$ & $37.9 \%$ & $30.5 \%$ \\
\hline $\begin{array}{l}\text { Authentic assessment reflects students' } \\
\text { competencies in applying their knowledge and } \\
\text { cognitive skills to solve substantive, } \\
\text { meaningful tasks. }\end{array}$ & $1.1 \%$ & $5.3 \%$ & $13.7 \%$ & $47.4 \%$ & $32.6 \%$ \\
\hline $\begin{array}{l}\text { Authentic assessment is time consuming and } \\
\text { labor intensive. }\end{array}$ & $11.6 \%$ & $4.2 \%$ & $32.6 \%$ & 28.45 & $23.2 \%$ \\
\hline $\begin{array}{l}\text { Time and effort spent on authentic assessment } \\
\text { exceed the benefits. }\end{array}$ & $8.4 \%$ & $3.25 \%$ & $24.2 \%$ & $33.7 \%$ & $30.5 \%$ \\
\hline
\end{tabular}

As it is shown in the table above, the majority of the participants agree with the statement that authentic assessment requires students to construct an original response and more critical thinking instead of choosing from multiple possible correct options, as one of the respondents stated, "Education must be informed by critical thought and applied knowledge". Also, it has been highly agreed that authentic assessment assesses the final product as well as the process of creating it. In addition, $81 \%$ of the participants agreed that assessment requires a collaborative effort to solve problems. More than a half of the participants believe that authentic assessment requires students to learn to evaluate their own work 
using predetermined criteria during authentic assessment and it is also based on giving students' explicit criteria. Moreover, authentic assessment uses collected students work and requires performance change evaluation as time passes. Surprisingly some of the respondents answered positively and agreed that time and efforts spent on authentic assessment exceed the benefits while the majority did not totally agree that authentic assessment lacks objectivity. These may have happened because the respondents misunderstood the question or have negative experience in using authentic assessment. An interview could be added to the survey to obtain more objective data. The respondents agreed that authentic assessment demonstrates students' abilities to utilize their knowledge and cognitive skills to perform meaningful real-life tasks. The respondents also believe that it is time consuming and labor intensive.

\subsection{Discussion}

This study's results revealed that authentic assessment was taken into consideration by the teachers. Regarding to application of authentic assessment, the results show that most of the teachers believe in effectiveness of authentic assessment and try to apply it to their lessons. Teachers do observations during the process of preparing the final products and they design their lessons to implement real life tasks in the classroom. However, when it comes to formal assessment most of the teachers are using the traditional assessment. This leads to weak connection between what is taught during the lessons, assessment, and learning objectives. That shows that in reality teachers are still not applying authentic assessment. 63.2\% of the respondent teachers stated that they make informal observations but in reality, as it was mentioned in the literature review, there are some obstacles that prevent us from implementing authentic assessment such as the lack of time, curriculum constraints, and the absence of the required facilities. It is true that the teachers are aware of the usefulness of authentic assessment, but they are very often unable to implement it. It was also found through this research that the most frequently used types of assessments were constructed response items and writing samples which can be considered as types of authentic assessment (O'Malley \& Pierce, 1996). However, the context and the procedures of those assessment tasks make the exam authentic or traditional, so the teachers should carefully analyze very single task to increase the authenticity of the tasks.

Moreover, most of the respondents agreed that authentic assessment assesses the process of creating final product directly but in authentic assessment very often the process of preparing is as much important as the final product. Sometimes the final product may not be very much important, what is important is the process of performing a task and vice versa. This is why a teacher should consider the learning outcome/s focusing on process or a final product since the attainment of the learning objective is essential in authentic assessment and in assessment in general.

Different from other types of traditional assessment, authentic assessment requires teachers to provide students with the assessment criteria before they start working on the assignment. So, during the process of preparation, they know what to focus on. Also, it has been found that majority of the participants design their lessons to help students to translate issues into meaningful, real life tasks and activities. In his perspective, authentic assessment with its capacity to foster higher level of critical thinking increases the possibility to achieve the learning objectives and prepare the students for the real-life situations (Wiggins, 1989; Winograd \& Perkins, 1995; O'Malley \& Pierce, 1996). 
The findings of this research aligned with the previous studies by Archbald and Newman (1988) Kerka (1995), Wiggins (1989) emphasizing the importance of authentic assessment in terms of training students to prepare them for their professional life through appropriate context, instruction, and assessment.

\section{Conclusion and Recommendations}

This study determined that authentic assessment in language teaching is still in its infancy in Erbil, Iraq, however with proper planning, teacher training, curriculum changes, and sufficient financial support it is not impossible to be implemented. As such, we would like to recommend that the stakeholders organize workshops and hands-on training sessions on authentic assessment for EFL teachers to increase the content knowledge on planning, constructing, and application of the authentic assessment in the classroom. The careful needs analysis, changes in the curriculum, provision of the resources (and/or the brainstorming on how the existing ones can be used effectively), as well as the support of the Ministry of Education and Ministry of High Education by opening a space for authentic assessment will sustainably impact on the quality of assessment and as a result of education in general.

\section{References}

Archbald, D., \& Newman, F. (1988). Beyond standardized testing: Assessing authentic academic achievement in the secondary school. Washington D.C. : National Association of Secondary School Principals.

Bachman, L., \& Palmer, A. (1995). Langauge tesing in practice. New York: Oxford University.

Bagnato, S. (2007). Authentic assessment for early childhood intervention. New York: Gulford Press.

Burke, K. (2009). How to assess authentic learning (5th ed.). Thousand Oaks: Corwin.

Butler, K. (2020). Authentic assessment in a university pathway program. In E. White, \& T. Bucher, classroom assessment for language teaching (pp. 298-325). Newcastle upon Tyne: Cambridge Scholars Publishing.

Capperucci, D. (2019). Assessment and certification of foreign language learning through rubric: A methodological perspective. In A. Lopes, \& R. R. Cecilia, New trends in foreign language teaching: methods, evaluation and innovation (pp. 294-308). Newcastle upon Tyne: Cambridge Scholoars Publishing.

Darling-Hammond, L., Falk, B. F., \& Ancess, J. (2017). Authentic assessment in action: Studies of schools and students at work. New York: Teachers College Press.

Ferguson, J. S. (2018). Using authentic assessment in information literacy programs: tools, techniques, and strategies. London: Rowman \& Littlefield.

Kerka, S. (1995). Techniques for authentic assessment. Practice application brief. ERIC clearinghouse on adult, career, and vocational education, 1-4. Retrieved from https://files.eric.ed.gov/fulltext/ED381688.pdf

O'Malley, J. M., \& Pierce, L. V. (1996). Authentic assessment for english language learners: Practical approaches for teachers. Boston: Addison-Wesley Publishing.

Ulker, V. (2017a). Impact of the alighnment between learning outcomes and assessemtn on english as a foreign language students' writing skills development (Ishik University Language Preparatory School Case). Journal of Education in Black Sea Region, 3(2017), 139-148.

Ulker, V. (2017b). The alignment of teaching methodology and learning outcomes: The effect of students' perceptions on the development of english language proficiency of adult learners. International Journal of Social Sciences \& Educational Studies, 4(3), 132-139. 
Ulker, V. (2017c). The design and use of speaking assessment rubrics. Journal of Educaion and Practice, 8(32), 135-140. Retrieved from https://core.ac.uk/download/pdf/234641197.pdf

Wiggins, G. (1989). A true test: Toward more authentic and equitable assessment. The Phi Delta Kappan, 70(9), 703-713. Retrieved from

https://grantwiggins.files.wordpress.com/2014/01/wiggins-atruetest-kappan89.pdf

Winograd, P., \& Perkins, F. (1995). Authentic assessment in the classroom: Principals and practices. In R. Blum, \& J. Artec, A handbook for student performance assessment in an era of restructuring (pp. 1-11). Alexandria: VA: Assosiation for Supervision and Curriculum Development. 